\title{
Actual Use and Continuous Use of Retail Mobile App: A Model Comparison Perspective
}

\author{
Sunday Adewale Olaleye ${ }^{1, *}$, Ismaila Temitayo Sanusi ${ }^{2}$, Bisola Adepoju ${ }^{3}$ \\ ${ }^{1}$ Oulu Business School, Department of MMI, University of Oulu, 90014, Finland \\ ${ }^{2}$ Philosophical Faculty, University of Eastern Finland, 80100 Joensuu, Finland \\ ${ }^{3}$ Texas Instrument, Dallas, Texas, 75243, United States
}

\begin{tabular}{l} 
A R T I C L E I N F O \\
\hline Article history: \\
Received: 09 July, 2018 \\
Accepted: 26 September, 2018 \\
Online: 14 November, 2018 \\
\hline Keywords: \\
Mobile app \\
Retail \\
Use \\
Continuous Use \\
Gratification \\
\end{tabular}

\section{Introduction}

There is an argument on the prominent status of a mobile application in contrast with a mobile website and web applications most especially in a retailing context. The mobile app is a challenger of the web app, mobile website and since its emergence in 2008, there are more than 700,000 different apps that operate on different operating systems platforms such as Android, Windows, and iOS [1]. The mobile app is "a type of software that allows the user to perform a specific task that can be installed and run on a range of portable digital devices such as smartphones and tablets". In [2], the author defines mobile app as "an IT software artefact that is specifically developed for mobile operating systems installed on handheld devices, such as smartphones or tablet computers". The two definitions reveal that mobile app cannot be used in isolation but through a device. A mobile app can be distinguished as software for smart mobile devices, it could

\footnotetext{
${ }^{*}$ Corresponding Author: Sunday Adewale Olaleye, University of Oulu, 90014,
}

Finland,+358466424139 sunday.olaleye@oulu.fi

\begin{tabular}{l} 
A B S T R A C T \\
\hline A mobile retail app is a growing innovation in a retailing setting and there is an argument \\
on the prominent status of a mobile application in contrast with a mobile website and web \\
applications. The study used quantitative data to run multiple regression analysis with keen \\
attention to linear regression assumption and compare four models for mobile retail app \\
use and continuous use based on mobile retail app technology, trust, and gratification. \\
Theoretically, the study integrates the unified theory of acceptance and use of technology \\
(UTAUT), trust and gratification and expand the technology acceptance model with the \\
trust and gratification elements. To have a better understanding of the hypothesized theory \\
and clearer perception of the model that have explanatory power, the study employs SPSS \\
linear regression and general linear regression to look at the relationship of mobile app \\
technology, trust and gratification predictors and the outcome variable. The study \\
emphasized the importance of trust, privacy assurance, learning and relaxation features in \\
a mobile retail app as an antecedent of its use and continuous use. This is a novel \\
contribution to the literature on technology acceptance and retailing. This study also shed \\
more light on the importance of age as a moderator of gender and marital status regarding \\
mobile retail app use and continuous use. Further, it also explicates the managerial \\
implication of mobile app and makes a necessary future recommendation.
\end{tabular}

be premium or freemium and downloadable through a centralized online market with an opportunity to rate and review based on the users' experience [3]. Despite the challenge of poor performance of some mobile retailing app, as at 2015, the global app revenue has soared to 8.3 billion dollars, and by the year 2020 mobile apps are predicted to reach 189 billion dollars in revenues [4]. A mobile app is dynamic and flexible for modification to meet the need of an individual retail store. A mobile app is attracting more customers daily and positively impacting the business of app developers, mobile device manufacturers and internet service providers [5-6]. Due to mobile app different potential and benefit, it is regarded as one of the fast-growing technology markets globally. A mobile app is an interesting research domain for the researchers and [6], integrates the Theory of Planned Behavior, the Technology Acceptance Model, and the Uses and Gratification Theory to examine the American consumers' mobile apps attitudes, intent, and use. Despite the result of this study, [2] discovered a gap in mobile app evaluation regarding theory and methodological clarity and recommended their instrument as an 


\section{S.A. Olaleye et al. / Advances in Science, Technology and Engineering Systems Journal Vol. 3, No. 6, 151-158 (2018)}

adequate measurement of a mobile app. Reference [1] explore app consumption and exploratory analysis of the uses and gratifications of mobile apps while [2] focus on mobile app usability, conceptualize and developed mobile app instrument for general use. Reference [7] investigates the intention of a mobile app to disclose their information dwelling on privacy calculus theory. In [5], the author suggested an expansive study of a mobile app to researchers. This mobile app study is country focused. Finland is a famous country in mobile banking and other emerging technologies. S Group, Finland's renown retailer won NACS Insight European Technology Implementation Award in 2016 for an added fueling feature for its S-mobile app. The S-mobile app exhibits three features of retail, banking and fuel services [8]. Kesko is another significant store chain in Finland with a 33.1\% share of the 16.7 billion euros retail market in 2014 with 900,000 customers in attendance of chain's 900 grocery stores every day. K-ruoka mobile app is being driven by its mission to make the daily lives of its grocery store customers easier with intelligent shopping tools [9]. A mobile app is futuristic but has a fundamental problem of short lifespan as the users delete it from the smart devices because of poor functionality and performance [10-11]. This study intends to compare four models for mobile retail app use and four models for mobile retail app continuous use based on mobile retail app technology, trust and gratification. The results of this research help to fill the gap that premature of mobile app use has created. The significant objective of this study is to examine how the combination of mobile retail app technology, trust and gratification model can extend the mobile retail app use and continuous use based on the optimised mobile app technology, increased trust confidence and embedded gratification elements and the sub-objective is to examine how to increase the mobile app user's autonomy and efficiency and to enrich the mobile app user's experience. To have a better understanding of the hypothesised theory and clearer perception of the model that have explanatory power, the study employs SPSS linear regression and general linear regression to look at the relationship of mobile app technology, trust and gratification predictors and the outcome variable. Further, it also explicates the managerial implication of mobile app and makes a necessary recommendation. The study is divided into five parts. The first section gives an overview of mobile app. The second section synthesizes applicable literature while section three explores the appropriate methodology for the study. Section four displays the data analysis and the result while the last section shows the theoretical and managerial implications with future study alertness.

\section{Literature Review and Hypotheses}

Based on UTAUT, Trust and Gratification model the researchers adopted two constructs include: Performance expectancy, and effort expectancy, social influence, facilitating condition, trust, security, privacy, cognitive, affection and tension free. These constructs have been proved in the literature as salient predictors for accepting technology. In this section, we define each of the constructs and their relationship.

\subsection{Performance Expectancy}

The level of belief by an individual that using the system will help to attain gains in job performance is known as Performance expectancy. In literature, performance expectancy plays a significant role in the intention to adopt information technology as shown in study [12-14]. This model is a combination of previous ones, five factors from last model helped information of performance expectancy variable consisting of perceived usefulness (technology acceptance models), external motivation (motivational model), job fit (PC utilization model), relative advantages (innovation diffusion theory) and outcome expectations (social cognition theory) [15-17]. The perception that using a mobile app will be more useful and improve performance will determine its use and continuous use.

\subsection{Effort Expectancy}

Effort expectancy is defined as "the degree of ease associated with the use of the system" [16]. This construct is a combination of three constructs from the existing models as stated by researchers. Such as perceived ease of use from the study of [18] [15] [19] and ease of use from [20]. The perception of comfort in using the mobile app will determine its purpose and continuous use.

\subsection{Social Influence}

Reference [21] defined Social influence as the degree of impact on the interaction among people in the social network. It was further described by [22] as the perceived pressure gained to perform a specific behavior. Service experiences from technology use can be shared by people to form a collective basis for conversations within a social network. Social influence perspective has been found to be significant in the adoption of innovative product and services [23-24]. From a social perspective, we consider that social ties predict mobile retail app use and usefulness in the current study.

\subsection{Facilitating Conditions}

Facilitating conditions refers to the extent to which an individual perceives that the technical and organizational infrastructure required to use the proposed system are available [16]. According to [15-17], the definition covers constructs of perceived behavioral control (planned behavior theory and decomposed planned behavior theory), facilitating conditions ( $\mathrm{PC}$ utilization model) and adaptability (innovation diffusion theory). Promoting Conditions is significantly related to technology use [25]. Technology-wise, there is a deep connection between PE, $\mathrm{EE}, \mathrm{SI}$ and $\mathrm{FC}$ as an influencing factor of mobile retail app actual use and continuous use and the study hypothesized that:

H1: Performance expectancy, social influence and facilitating condition were predictors of mobile retail app use and usefulness.

H2: Performance expectancy and effort expectancy are predictors of mobile retail app continuous use.

\subsection{Trust}

According to [26], trust promotes transaction success because it can reduce social uncertainties that would otherwise be too complex, if not impossible, to figure out on a rational basis. 


\section{S.A. Olaleye et al. / Advances in Science, Technology and Engineering Systems Journal Vol. 3, No. 6, 151-158 (2018)}

Online purchase requires consumer trust since consumers have to provide their personal information during the transaction process. [27] and [28], found trust to be a key predictor of both initial online purchase and repeat purchase. Trust has also been found to be significant in decision making for online transactions [29-30]. To obtain the necessary assurance, [31] opined that customers must depend more heavily on trust in the online vendor. [32] states that consumers rely on their trust in the vendor or the Internet to mitigate the effects of their uncertainty toward their relationships (as buyer and seller) in the online environment. In this study, it is proposed that users trust in the mobile app use will motivate its continuous use.

\subsection{Security}

Security threats have really been a point of concern in the online environment, threats such as fraudulent access or attack on consumer's mobile devices and online accounts. According to [33], in an internet context, security refers to the perceptions about safety regarding the means of payment and the mechanism for storing and transmission of information. [34] explains security as the consumer belief that their data will not be abused or their stored data cannot be modified by third parties without permission as data can only be seen by authorized individuals and certain actions can only be undertaken if proper authentication has taken place. [35] opined that an individual's perceived need for security should influence the perception of the usefulness of the device which is confirmed in the study of [36] that users show concern about unsecured websites. In this study, security concerns measure respondents' belief that security concerns of the mobile app will affect its use.

\subsection{Privacy}

The need for confidentiality of individuals becomes a significant challenge considering an automatic exchange of different personal information. Privacy concerns, especially through technology platform, must be addressed to maintain user control. Lessig defines privacy as the combination of "empowerment to control", "utility to protect", "dignity to establish an equilibrium", and "regulating agent to balance power" [37]. [38] opined that privacy is considered to exist when users of technology can control their personal information. Reference [39] found that users' perception of privacy assurance affects the use of a mobile platform. Thus, continuous use could probably be predicted by privacy confidence. Privacy assurance and a secured mobile retail app are antecedents of trust. The retail mobile app users will go an extra mile when they are assured that the mobile app they are using secured with privacy confidence. Regarding this proposition, the study hypothesized that:

H3: Trust and security perception are predictors of mobile retail app use and usefulness.

H4: Privacy confidence is a predictor of mobile retail app continuous use.

\subsection{Cognitive}

According to [40], cognitive factors related to mobile technology are important to examine because they influence the users' feelings about a technology. The cognitive phase represents the conscious decisions regarding the behavioral purpose of serving the users' needs [41]. The cognitive comprises of some factors such as the perceived usefulness of the mobile app, confirmation of expectations, and contextual factors/characteristics of the system (i.e., perceived mobility, personalization, and responsiveness). These factors have been found to positively influence the use and continuous use of a system [42-45].

\subsection{Affective}

The behaviors that capture the personal feelings users have about an object that affects their behavior is known as affective [46]. According to [41], affect can exhibit positive or negative feelings about an object and provide an evaluation of the product and is considered an essential part of users' attitude. Zhang found that affect has a strong impact on decision-making behavior and consumer shopping behavior, which suggests that affect helps explain significant variance in one's cognition and behavior (Zhang, 2013). Affective factors have been found to be significant in IT use and continuance intention [45].

\subsection{Tension Free}

The current study examines the gratification among other constructs as an antecedent of mobile app continuous use in the retailing setting. The use and gratification theory posit that the use of media and technology is determined by individual users needs or motivations [47-48]. Uses and gratification research has highlighted consumers' hedonistic motives for using new communication technology, the need for entertainment, pleasure or enjoyment (Shin, 2007; Huang, 2008) [49-50]. Reference [51] sees gratification as the extent that the customers' needs are satisfied, while they assert that the stronger the degree of gratification, the higher the intention to use mobile apps. It was further stressed that some mobile app has gratification features that can calm tension while findings show that tension-free features on mobile apps positively affects the use of retailing mobile apps [51]. Mobile retail app with gratification elements will create an avenue for users learning, pleasure and tension calmness. It is therefore hypothesized that:

H5: Cognitive, affective, and tension free as an element of gratification were predictors of mobile retail app use and usefulness.

H6: Cognitive, affective, and tension free as an element of gratification were predictors of mobile retail app continuous use.

\subsection{Actual Use}

This construct was used in theories such as unified theory of acceptance and use of technology (UTAUT) by [18] which aims to explain user intentions to use an information system and subsequent usage behavior. Also, the Technology Acceptance Model (TAM) by [15], which is an information systems theory that models how users come to accept and use technology. Actual usage is used in the study as the actual use of the retail mobile app. Because of some antecedent behaviors, e.g. trust, privacy confidence in the platform and facilitating conditions.

\subsection{Continuous Use}

After the actual usage of a new technology or system, constant use is the next. This is the subsequent usage behavior of 
a platform. At the level of continuous usage of a system, the antecedent of usage of that system comes to play, whereby experience and knowledge of the previous usage suggest constant use.

It is more profitable for the mobile retail app users to use the facilities embedded into the app and to enjoy it. This initial gratification, efficiency perception and assurance of security will motivate them to continue to use the retail app. Based on this view, the study hypothesized that:

H7: Combined elements of technology and gratification are predictors of mobile retail app use and usefulness.

H8: Combined elements of technology, trust and gratification were predictors of mobile retail app continuous use.

\section{Research Design and Methodology}

\subsection{Sample and Data Collection}

Purposeful sampling methodology was employed to gather the views and opinion of respondents online. This sampling method was used because only users of a mobile retail app in recent times or in the time past are the respondent target. Users that have used a mobile retail app to view products videos view current products new arrivals, shop and purchase products, received sales and coupon alerts, view products reviews and view products description, specifications and details. The total respondents that attended to the online questionnaire are 235. The data was subjected to a reliability test of Cronbach Alpha to ascertain the reliability of the instrument used and the results reach and above the threshold of 0.7 with a minimum of 0.87 and a maximum of 0.96 .

\subsection{Measurement}

In this study, items were adopted to measure the twelve latent variables from works of literature. Items Measuring Performance expectancy, Effort expectancy, Social influence, Facilitating conditions and Behavioral intention adopted from [16] user acceptance of information technology scale. Items Measuring Use behavior adopted from [2] mobile application usability scale). Items Measuring continuous use adopted from [52] expectation disconfirmation and technology adoption scale). Items Measuring cognitive, affective and tension free adopted from [53] Use and gratifications of mobile SNSs scale. Items Measuring tension free adopted from [54] the uses and gratifications of using Facebook music listening applications scale). Items Measuring affective adopted from [55] uses and gratifications theory and e-consumer behaviors scale. Items Measuring trust adopted from [56] addressing the personalization-privacy paradox scale. Items Measuring privacy and security adopted from [57] consumer trust, perceived security and privacy policy scale. The first section of the four parts of the instrument used to elicit information features the demography detail of the mobile app users followed by mobile app users experience. The next section extracts information on mobile app usage and the fourth section elicit a question from respondents on seven Likert Scale type question from strongly disagree (1) to strongly agree (7) based on the theories and works of literature reviewed.

Table 1: Regression Analysis result for retail mobile app use

\begin{tabular}{|c|c|c|c|c|c|c|c|c|c|c|}
\hline Models (AU) & $\beta$ & SE & St. $\beta$ & $\mathrm{T}$ & $\mathrm{R}$ & $\mathrm{R}^{2}$ & Adj. $R^{2}$ & AIC & SE & $\mathrm{F}$ \\
\hline \multicolumn{11}{|l|}{$\begin{array}{l}\text { RMA } \\
\text { Technology }\end{array}$} \\
\hline Constant & -.46 & .240 & & -1.91 & .824 & .679 & .674 & 559.8 & .786 & 162.6 \\
\hline $\mathrm{PE}$ & .74 & .046 & .684 & 16.03 & & & & & & \\
\hline SI & .20 & .050 & .166 & 3.98 & & & & & & \\
\hline FC & .13 & .040 & .125 & 3.12 & & & & & & \\
\hline \multicolumn{11}{|l|}{ RMA Trust } \\
\hline Constant & 1.64 & .256 & & 6.41 & .540 & .292 & .286 & 743.5 & 1.165 & 47.75 \\
\hline TR & .366 & .099 & .354 & 3.68 & & & & & & \\
\hline SE & .204 & .093 & .210 & 2.19 & & & & & & \\
\hline \multicolumn{11}{|l|}{$\begin{array}{l}\text { RMA } \\
\text { Gratification }\end{array}$} \\
\hline Constant & .492 & .200 & & 2.459 & .778 & .605 & .600 & 608.1 & .871 & 118.1 \\
\hline $\mathrm{CO}$ & .458 & .062 & .433 & 7.44 & & & & & & \\
\hline $\mathrm{AF}$ & .275 & .086 & .263 & 3.19 & & & & & & \\
\hline TF & .157 & .075 & .163 & 2.11 & & & & & & \\
\hline \multicolumn{11}{|c|}{ Combined Models } \\
\hline Constant & -.53 & .222 & & -2.37 & .848 & .719 & .714 & 530.9 & .737 & 146.8 \\
\hline $\mathrm{PE}$ & .580 & .051 & .539 & 11.27 & & & & & & \\
\hline FC & .107 & .038 & .108 & 2.82 & & & & & & \\
\hline $\mathrm{CO}$ & .316 & .051 & .299 & 6.18 & & & & & & \\
\hline Continent & .127 & .044 & .105 & 2.90 & & & & & & \\
\hline
\end{tabular}

$* * * \leq 0.0001 . * * 0.001<\mathrm{p} \leq 0.01,{ }^{*} 0.01<\mathrm{p} \leq 0.05$

MRA: Retail Mobile App $\beta$ : Beta, SE: Standard Error, SE: Standard error,

St. $\beta$ : Standardized beta, SE: Standard error, T: T-test

$\mathrm{R}^{2}$ : Coefficient of determination, F: F-test.

Dependent variable: AU - App use, Predictors: PE: Performance Expectancy, SI: Social Influence, FC: Facilitating Condition, TR: Trust, SE: Security, CO: Cognitive, AF: Affective 
Table 2: Regression Analysis result for retail mobile app continuous use

\begin{tabular}{|l|l|l|l|l|l|l|l|l|l|l|}
\hline Models (CU) & B & SE & St. $\beta$ & T & R & $\mathrm{R}^{2}$ & Adj. R & AIC & SE & F \\
\hline $\begin{array}{l}\text { RMA } \\
\text { Technology }\end{array}$ & & & & & & & & & & \\
\hline Constant & .163 & .26 & & .63 & .78 & .61 & .60 & 618.7 & .893 & 178.9 \\
\hline PE & .795 & .05 & .72 & 14.7 & & & & & & \\
\hline EE & .121 & .06 & .10 & 2.1 & & & & & & \\
\hline RMA Trust & & & & & & & & & & \\
\hline Constant & 1.912 & .24 & & 8.1 & .55 & .31 & .30 & 750.4 & 1.18 & 102.4 \\
\hline PR & .545 & .05 & .55 & 10.1 & & & & & & \\
\hline $\begin{array}{l}\text { RMA } \\
\text { Gratification }\end{array}$ & & & & & & & & & & \\
\hline Constant & .677 & .21 & & 3.2 & .76 & .58 & .57 & 637.2 & .927 & 105.5 \\
\hline CO & .361 & .07 & .33 & 5.5 & & & & & & \\
\hline AF & .346 & .09 & .32 & 3.8 & & & & & & \\
\hline TF & .187 & .08 & .19 & 2.4 & & & & & & \\
\hline Combined Models & & & & & & & & & & \\
\hline Constant & -.072 & .21 & & -.35 & .82 & .68 & .67 & 537.0 & .816 & 119.3 \\
\hline PE & .497 & .07 & .45 & 7.6 & & & & & & \\
\hline PR & .124 & .05 & .13 & 2.7 & & & & & & \\
\hline CO & .180 & .06 & .17 & 2.9 & & & & & & \\
\hline AF & .221 & .07 & .21 & 3.4 & & & & & & \\
\hline
\end{tabular}

$* * * \leq 0.0001 . * * 0.001<\mathrm{p} \leq 0.01, * 0.01<\mathrm{p} \leq 0.05$

RMA: Retail Mobile App. $\beta$ : Beta, SE: Standard Error, SE: Standard error, St. $\beta$ : Standardized beta, SE: Standard error, T: T-test,

$\mathrm{R}^{2}$ : Coefficient of determination, F: F-test.

Dependent variable: CU - Continuous use, Predictors: PE: Performance Expectancy, SI: Social Influence, FC: Facilitating Condition, TR: Trust, SE: Security, CO: Cognitive, AF: Affective

\section{Results}

\subsection{Multiple Regression Model}

The study used quantitative data to run multiple regression analysis with keen attention to linear regression assumption. The study used SPSS 24 version to ensure that the prediction errors are independent over cases, follow a normal distribution, lack heteroscedasticity and have a constant variance (homoscedasticity) and the relationship among the variables are linear. In order not to violate the assumptions, the study undertakes the following steps. We examined the factorability of the 48 items and used several criteria. Initially, 45 items correlated with other items (.215 - .841), indicating reasonable factorability. Secondly, the Kaiser-MeyerOlkin measure of sampling adequacy was .94 , above the rule of thumb of .6, and Bartlett's test of sphericity was significant $(\chi 2$ $(990)=11678.29, \mathrm{p}<.001)$. Finally, the commonalities were all above .5, confirming that each item shared some common variance with other items. Based on the overall indicators, factor analysis was conducted with 45 items.

The study variables did not contain any system missing values and the frequency distributions look plausible. The descriptive statistics test for mean was $(2.91-5.39)$ and standard deviation $(1.29$ - 1.64). The plotted scatterplots of the predicted values ( $\mathrm{x}$ axis) with the outcome variables (y-axis) did not show any clear curvilinearity. Cronbach Alpha ranges between (.972 - .974) and the variance inflation factors (VIFs) are lower than 10 (Myers, 1990) [58], the tolerances greater than 0.2 (Menard, 1995) [59] and the condition index less than 30 . In all, the chart plotter, and the data analysis did not show any violation of the independence, homoscedasticity and linearity assumptions.
The author run linear regression analysis for four models for technology, trust and gratification predictors as against mobile retail app use and continuous use. All the predictors of mobile retail app (Model 1) were significant, performance expectancy $\rightarrow$ mobile app use $(\beta=0.68, \mathfrak{t}=16.03, \mathrm{P}$ Value $=<.001)$, social influence $\rightarrow$ mobile app use $(\beta=0.17, \mathrm{t}=3.98, \mathrm{P}$ Value $=<.05)$, facilitating conditions $\rightarrow$ mobile app use $(\beta=0.13, t=3.12$, $P$ Value $=<.05$ ). Mobile retail app trust (Model 2 ) trust $\rightarrow$ mobile app use, $(\beta=0.35, \mathrm{t}=3.68, \mathrm{P}$ Value $=<.05)$, security $\rightarrow$ mobile app use, $(\beta=0.21, t=2.19, P$ Value $=<.05)$. Mobile retail app gratification (Model 3) cognitive $\rightarrow$ mobile app use, $(\beta=0.43, t=7.44$, P Value $=<.05)$, affective $\rightarrow$ mobile app use, $(\beta=0.26, \mathrm{t}=3.19, \mathrm{P}$ Value $=$ $<.05)$, tension free $\rightarrow$ mobile app use, $(\beta=0.16, \mathrm{t}=2.11, \mathrm{P}$ Value $=$ $<.05$ ). Combined models (Model 4) performance expectancy $\rightarrow$ mobile app use, $(\beta=0.54, \mathrm{t}=11.27, \mathrm{P}$ Value $=<.001)$, facilitating conditions $\rightarrow$ mobile app use, $(\beta=0.11, \mathrm{t}=2.82$, P Value $=<.05)$, cognitive $\rightarrow$ mobile app use, $(\beta=0.30, \mathrm{t}=6.18$, $\mathrm{P}$ Value $=<.05)$, continents $\rightarrow$ mobile app use, $(\beta=0.11, \mathrm{t}=2.90$, $\mathrm{P}$ Value $=<.05)$.

For continuous use all the predictors of mobile retail app (Model $1)$ were significant, performance expectancy $\rightarrow$ mobile app continuous use $(\beta=0.72, \mathrm{t}=14.67, \mathrm{P}$ Value $=<.001)$, effort expectancy $\rightarrow$ mobile app continuous use $(\beta=0.10, t=2.11, P$ Value $=<.05$ ). Mobile retail app trust (Model 2) privacy $\rightarrow$ mobile app continuous use, $(\beta=0.55, \mathrm{t}=10.12$, $\mathrm{P}$ Value $=<.05)$. Mobile retail app gratification (Model 3) cognitive $\rightarrow$ mobile app continuous use, $(\beta=0.33, \mathrm{t}=5.51, \mathrm{P}$ Value $=<.05)$, affective $\rightarrow$ mobile app continuous use, $(\beta=0.32, \mathrm{t}=3.77, \mathrm{P}$ Value $=<.05)$, tension free $\rightarrow$ mobile app continuous use, $(\beta=0.19, \mathrm{t}=2.35, \mathrm{P}$ Value $=<.05$ ). Combined models (Model 4) performance expectancy $\rightarrow$ mobile app continuous use, $(\beta=0.45, \mathrm{t}=7.64, \mathrm{P}$ 


\section{S.A. Olaleye et al. / Advances in Science, Technology and Engineering Systems Journal Vol. 3, No. 6, 151-158 (2018)}

Value $=<.001)$, privacy $\rightarrow$ mobile app continuous use, $(\beta=0.13$, $\mathrm{t}=2.71, \mathrm{P}$ Value $=<.05)$, cognitive $\rightarrow$ mobile app continuous use, $(\beta=0.17, \mathrm{t}=2.91, \mathrm{P}$ Value $=<.05)$, affective $\rightarrow$ mobile app continuous use, $(\beta=0.21, \mathrm{t}=3.40, \mathrm{P}$ Value $=<.05)$.

\subsection{Model Comparison}

The study model is multistage indicating the need for general linear regression analysis. We conducted general linear analysis for model comparison, and we extracted the value of Akaike Information Criterion (AIC) and compared it with the coefficient of determination. The first model of mobile retail app (mobile retail app technology) revealed $\mathrm{AIC}=559.76, \mathrm{R}^{2}=67.9 \%$, model 2 (mobile retail app trust) $\mathrm{AIC}=743.52, \mathrm{R}^{2}=29.2 \%$, model 3 (mobile retail gratification) $\mathrm{AIC}=608.12, \mathrm{R}^{2}=60.5 \%$, and model 4 (combined models) $\mathrm{AIC}=530.93, \mathrm{R}^{2}=71.9 \%$. According to the rule of thumb of linear model assessment, the lower the AIC, the better and the higher the coefficient of determination the better. In this study, the combined model of technology, gratification and continent had the lowest AIC and the highest $\mathrm{R}^{2}$.

Similarly, to mobile retail app use, the continuous use first model of mobile retail app (mobile retail app technology) revealed AIC $=618.66, \mathrm{R}^{2}=60.7 \%$, model 2 (mobile retail app trust) $\mathrm{AIC}=$ $750.42, \mathrm{R}^{2}=30.5 \%$, model 3 (mobile retail gratification) $\mathrm{AIC}=$ $637.20, \mathrm{R}^{2}=57.8 \%$, and model 4 (combined models) $\mathrm{AIC}=$ $537.02, \mathrm{R}^{2}=67.5 \%$. The combined model of technology, trust and gratification had the lowest AIC and the highest $\mathrm{R}^{2}$.

\subsection{Moderation Effects}

A two-way analysis of variance was conducted on the influence of two independent variables (gender, marital status) on the age of mobile retail app users. Marital status included four levels (single, married, cohabitation, divorcement) and gender consisted of two levels (male, female). All effects were statistically significant at the .05 significance level except for the gender factor. The main effect for marital status yielded an $\mathrm{F}$ ratio of $\mathrm{F}(3$, $227)=57.7, \mathrm{p}<.001$, indicating a significant different between male $(\mathrm{M}=2.35, \mathrm{SD}=1.32)$, female $(\mathrm{M}=2.05, \mathrm{SD}=1.17)$. The main effect for gender yielded an $\mathrm{F}$ ratio of $\mathrm{F}(1,227)=0.004$, $\mathrm{p}>.005$, indicating that the main effect for gender was not significant. The interaction effect was significant, $F(3,227)=3.62$, $\mathrm{p}<.014$. In this case, the effect for gender interacts with marital status. That is, age affects females differently than males.

\section{Discussion, Theoretical and Practical Implications}

The goal of this study was to examine the impact of combined model of a mobile retail app on mobile retail app use and continuous use based on the optimised mobile app technology, increased trust confidence and embedded gratification elements and how the integrated model can enhance mobile app user's experience. Using SPSS, linear regression and general linear regression statistical technique were used.

Eight hypotheses were tested and supported. Out of the eight hypotheses, four focused on mobile retail app use and usefulness while the other four dwells on mobile retail app continuous use. Performance expectancy being the technology acceptance variable was the highest predictor of mobile app use in the first model. In addition to performance expectancy, social influence and facilitating conditions were found significant as predictors of mobile app use. There is an influence of the third parties such as mentors, relatives, and the retailers on the retailing customers to use a mobile retail app but the social influence variable was not significant as a predictor of mobile retail app continuous use. In model two, trust and security are the predictors of mobile app use while three elements, cognitive, affective and tension free of gratification predicted mobile retail app and cognitive was the highest predictor. To get more insight from the study, the study combined the three models of technology, trust and gratification and performance expectancy, facilitating conditions, cognitive and continent path coefficient with the mobile retail app were significant. Respondents that lived in Finland from Europe, Asia and Africa participated in the study, and the result shows the neutral response of the Europeans to the mobile retail app while Asia and Africa's response supported the use of mobile retail app. The Europeans users are indifferent while the Asia and Africa users in Finland are enthusiastic. Performance expectancy still maintained the highest predictor of a mobile retail app. Extant studies emphasised the role of performance expectancy in technology use [60-61].

Unlike mobile retail app use model one, only two variables are the predictors of mobile retail app continuous use and effort expectancy that was not found significant in mobile retail app use was substantial in a constant model. This can be explained that mobile retail app users have been using for a long period of time and its use is not cumbersome to the users any more. Only privacy confidence was significant in model two and it is an indication that privacy assurance will prolong the mobile retail app continuous use. Like the mobile retail app model three all the gratification elements were significant and coincidentally, cognitive was the highest predictor of mobile retail app continuous use. This signifies the importance of learning as the retailers add more features to their mobile app, there will be a need for the mobile retail app to learn how to use the new features either through a video or text instructions. The model four showcase performance expectancy, privacy, cognitive and affective as a predictor of mobile retail app continuous use but continent was not significant. In all the model, the mobile retail use and continuous combined model of technology, trust and gratification were found more robust than others. In addition to model comparison, the interaction effects of gender and marital status reveals that different age brackets influence gender differently based on four levels of marital status.

A mobile retail app is a growing innovation in a retailing setting, and theoretically, the study integrates the unified theory of acceptance and use of technology (UTAUT), trust and gratification and expand technology acceptance model with the trust and gratification elements. The study emphasized the importance of trust, privacy assurance, learning and relaxation features in a mobile retail app as an antecedent of its use and continuous use. This is a novel contribution to the literature on technology acceptance and retailing. This study also shed more light on the importance of age as a moderator of gender and marital status regarding mobile retail app use and continuous use. 


\section{S.A. Olaleye et al. / Advances in Science, Technology and Engineering Systems Journal Vol. 3, No. 6, 151-158 (2018)}

Practically, the retailing managers and the technology professionals need to put age, gender, marital status and people from different continents into consideration when they are strategizing for the mobile retail app use and continuous use. The add-on technology, hedonic and trust features should factor in the demographic profile of the mobile retail app. Second, the retailer should reposition their mobile app as a multitasking app of an information database for online e-shopping, gamification for rewards and video curation for socialization.

\subsection{Limitations and Future Research}

The mobile app market is vast, and this study only focuses on retailing segment which may not represent the state-of-the-art of mobile app market. Due to this limitation, the future researcher in the mobile app research stream should conduct a mobile app comparative study with a focus on countries and different business sectors. The prospective studies also should use structural equation modelling (SEM) to compare different mobile app users intrinsic and extrinsic motivation.

\section{Conflict of Interest}

The authors declare no conflict of interest.

\section{References}

[1] R.N. Gerlich, K. Drumheller, J. Babb, D. Armond, “App consumption: An exploratory analysis of the Uses \& Gratifications of mobile apps" Academy of Marketing Studies Journal, 19(1), 69, 2015.

[2] H. Hoehle, V. Venkatesh, "Mobile Application Usability: Conceptualization and Instrument Development. MIS Quarterly, 39(2), 2015.

[3] C.Z. Liu, Y.A. Au, H.S. Choi, "Effects of freemium strategy in the mobile app market: an empirical study of Google play" Journal of Management Information Systems, 31(3), 326-354, 2014.

[4] A. Coleman, "Behind Sumoing's App Store Success: Finland's Mobile Tech Legacy" $2016 . \quad$ Available at: https://www.forbes.com/sites/alisoncoleman/2016/04/24/behind-sumoingsapp-store-success-finlands-mobile-tech-legacy/\#385b8077668c. Cited on 21.12.2017.

[5] R. Garg, R. Telang, "Inferring app demand from publicly available data". MIS Quarterly, 37(4), 1253-1264, 2013.

[6] H.C. Yang, "Bon Appétit for apps: young American consumers' acceptance of mobile applications" Journal of Computer Information Systems, 53(3), 85-96, 2013.

[7] T. Wang, T.D. Duong, C.C. Chen, "Intention to disclose personal information via mobile applications: A privacy calculus perspective" International Journal of Information Management, 36(4), 531542,2016

[8] D. Munford, "S Group innovates with mobile payment technology at the petrol pump" 2017. Available at: https://www.linkedin.com/pulse/groupinnovates-mobile-payment-technology-petrol-pump-dan-munford/. Cited on 21.12.2017.

[9] M, Kakko, "Mobile app makes customers' daily lives easier - K-ruoka" 2017. Available at: https://futurice.com/cases/k-ruoka-mobile. Cited on: 21.12.2017.

[10] eMarketer, "Why Consumers Download, and Delete, a Retailer's Mobile App, Promos and rewards drive downloads" 2016. Available at: https://www.emarketer.com/Article/Why-Consumers-Download-DeleteRetailers-Mobile-App/1014212. Cited on: 21.12.2017.

[11] Insights, "Retail Apps: Why Consumers Download, Use, and Delete" 2017. Available at: http://newsroom.synchronyfinancial.com/documentlibrary/retail-app-engagement. Cited on: 21.12.2017.

[12] I. Benbasat, H. Barki, "Quo vadis TAM?" Ournal of the Association for Information Systems, 8(4), 212-218, 2007.

[13] L. Carter, L.C. Schaupp, M.E. McBride, "The U.S. E-file initiative: An investigation of the antecedents to adoption from the individual" E-service Journal, 7(3), 2-19, 2011.

[14] M.N. Alraja, "User acceptance of information technology: A field study of an e-mail system adoption from the individual students' perspective" Mediterranean Journal of Social Sciences, 6(6), 19-25, 2005.
[15] F.D. Davis, R.P. Bagozzi, P.R. Warshaw, "User Acceptance of Computer Technology: A Comparison of Two Theoretical Models". Management Science. 35(8), 982-1002, 1989.

[16] V. Venkatesh, M.G. Morris, G.B. Davis, F.D. Davis, "User Acceptance of Information Technology: Toward A Unified View” MIS Quarterly. 27(3), $425-478,2003$.

[17] V. Venkatesh, F.D. Davis, “A Theoretical Extension of the Technology Acceptance Model: Four Longitudinal Field Studies" Management of Science, 46(2): 186-204, 2000.

[18] F.D. Davis, "Perceived Usefulness, Perceived Ease of Use, and User Acceptance of Information Technology". MIS Quarterly. 13(3), 319-339, 1989.

[19] R.L. Thompson, C.A. Higgins, J.M. Howell, "Personal Computing: Toward a Conceptual Model of Utilization" MIS Quarterly, 15(1), 124-143, 1991.

[20] G.C. Moore, I. Benbasat, I. "Development of an Instrument to Measure the Perceptions of Adopting an Information Technology Innovation" Information Systems Research. 2(3), 192-222, 1991.

[21] R.E. Rice, C. Aydin, "Attitudes toward new organizational technology: network proximity as a mechanism for social information processing. Adm. Sci. Q. 36 (2), 219-244, 1991.

[22] V. Venkatesh, S.A Brown, "A longitudinal investigation of personal computers in homes: adoption determinants and emerging challenges". MIS Quartely, 25 (1), 71-102, 2001.

[23] O. Turel, A. Serenko, N, Bontis, "User acceptance of wireless short messaging services: deconstructing perceived value" Inf. Manag. 44 (1), 63 73, 2010.

[24] V. Venkatesh, J.Y.L. Thong, X. Xu, "Consumer acceptance and use of information technology: extending the unified theory of acceptance and use of technology. MIS Quarterly 36 (1), 157-178, 2012.

[25] G.E. Heilman, G.A. Johnson, G.O. Seshie, B. Greene, "Perceived effect of facilitating conditions on college student computer use" Journal of Academy of Business and Economics, 9(2), 148-151, 2009.

[26] N. Luhmann, Trust and Power, London: John Wiley \& Sons, 1979.

[27] C. Flavian, M. Guinaliu, R. Gurrea, "The Role Played by Perceived Usability, Satisfaction and Consumer Trust on Website Loyalty," Information \& Management, 43, 1-14, 2006.

[28] I. Qureshi, Y. Fang, E. Ramesy, P. McCole, P. Ibboston, D. Compeau, "Understanding Online Customer Repurchasing Intention and the Mediating Role of Trust: An Empirical Investigation in Two Developed Countries" European Journal of Information Systems, 18(3),205-222, 2009.

[29] P.A. Pavlou, "Consumer acceptance of electronic commerce: integrating trust and risk with the technology acceptance model" Int. J. Electron. Commer, 7(3), 101-134, 2003.

[30] B.J. Corbitt, T. Thanasankit, H. Yi, "Trust and e-commerce: a study of consumer perceptions”. Electron. Commer. Res. Appl. 2(3),203-215, 2003.

[31] C.L. Corritore, B. Kracher, S. Wiedenbeck, "On-Line Trust: Concepts, Evolving Themes, a Model," International Journal of Human-Computer Studies 58(6), 737-758, 2003.

[32] S. Ha, L. Stoel, "Promoting customer-retailer relationship building: Influence of customer trustworthiness of customer loyalty programme marketing" Journal of customer behaviour 7(3), 215-229, 2008.

[33] A. Kolsaker, C. Payne, "Engendering trust in e-commerce: a study of genderbased concerns", Marketing Intelligence and Planning, 20(4), 206-14, 2002.

[34] M. Mandić, "Privacy and Security in E-Commerce". TRŽIŠTE, 21(2), 247 $260,2009$.

[35] T. James, T. Pirim, K. Boswell, B. Reithel, R. Barkhi, "An Extension of the Technology Acceptance Model to Determine the Intention to Use Biometric Devices" In Ed. Steve Clarke End User Computing Challenges and Technologies: Emerging Tools and Applications, IGI Global, 57-78, 2008.

[36] M.H. Shah, R. Okeke, R. Ahmed, "Issues of Privacy and Trust in ECommerce: Exploring Customers' Perspective" Journal of Basic Applied Science Research, 3(3), 571-577, 2013.

[37] L. Lessig, Code and other laws of cyberspace. Basic books, 1999.

[38] H. McCloskey, "Privacy and the right to privacy" Philosophy, 55(211), 17 38, 1980.

[39] S. Pearson, "Taking account of privacy when designing cloud computing services" In Software Engineering Challenges of Cloud Computing. CLOUD'09. ICSE Workshop, 44-52, 2009, IEEE.

[40] M.B. Holbrook, "Beyond attitude structure: Toward the informational determinants of attitude" Journal of Marketing Research, 545-556, 1978.

[41] L. Cobos, "Determinants of continuance intention and word of mouth for hotel branded mobile app users. Electronic Theses and Dissertations. 5719, 2017. http://stars.library.ucf.edu/etd/5719

[42] A. Bhattacherjee, G. Premkumar, "Understanding changes in belief and attitude toward information technology usage: a theoretical model and longitudinal test” MIS Quarterly, 229-254, 2004. 
[43] A. Bhattacherjee, C.P. Lin, "A unified model of IT continuance: three complementary perspectives and crossover effects" European Journal of Information Systems, 24(4), 364- 373, 2015.

[44] Z. Zhong, J. Luo, M. Zhang, "Understanding antecedents of continuance intention in mobile travel booking service" International Journal of Business and Management, 10(9), 156, 2015.

[45] A. Nabavi, M.T. Taghavi-Fard, P. Hanafizadeh, M.R. Taghva, "Information Technology Continuance Intention: A Systematic Literature Review" International Journal of E-Business Research (IJEBR), 12(1), 58-95, 2016.

[46] I. O. Pappas, P.E. Kourouthanassis, M.N. Giannakos, V. Chrissikopoulos, "Explaining online shopping behavior with fsQCA: The role of cognitive and affective perceptions. Journal of Business Research, 69(2), 794-803, 2016.

[47] J.G. Blumler, E. Katz, "The uses of mass communications: current perspectives on gratification research". Sage publication, Beverly Hills, CA, 1974.

[48] C.A. Lin, "Looking back: The contribution of Blumler and Katz's uses of mass communication" Journal of Broadcasting and Electronic media, 40(4), 574-681, 1996.

[49] D. Shin, "User acceptance of mobile internet: Implications for convergence technologies" Interacting with Computers, 19(4), 472-483, 2007.

[50] E. Huang, "Uses and Gratification in e-consumers" Internet Research, 18(4), 405-426, 2008.

[51] S.A. Olaleye, J. Salo, I.T. Sanusi, A. Okunoye, "Retailing Mobile App Usefulness: Customer Perception of Performance, Trust and Tension Free. International Journal of E-Services and Mobile Applications (IJESMA). 10(4), 1-17, 2018.

[52] V. Venkatesh, S. Goyal, "Expectation disconfirmation and technology adoption: polynomial modeling and response surface analysis" MIS quarterly, 281-303, 2010.

[53] Y.W. Ha, J. Kim, C.F. Libaque-Saenz, Y. Chang, M.C. Park, "Use and gratifications of mobile SNSs: Facebook and KakaoTalk in Korea". Telematics and Informatics, 32(3), 425-438, 2015.

[54] A. E. Krause, A. C. North, B. Heritage, "The uses and gratifications of using Facebook music listening applications". Computers in Human Behavior, 39, 71-77, 2014

[55] Y. Lu, W. Beck. Do you see what I see? Infants' reasoning about others' incomplete perceptions. Developmental Science, 13(1), 134-142, 2010.

[56] J. Sutanto, E., Palme, C.H. Tan, C.W. Phang, "Addressing the Personalization-Privacy Paradox: An Empirical Assessment from a Field Experiment on Smartphone Users". MIS Quarterly, 37(4), p. 1141-1164, 2013.

[57] C. Flavián, M. Guinalíu, "Consumer trust, perceived security and privacy policy: three basic elements of loyalty to a web site". Industrial Management \& Data Systems, 106(5), 601-620, 2006.

[58] R.H. Myers, "Classical and modern regression with applications, 2nd edition. PWS Kent, Boston, MA, 1990.

[59] S. Menard, Applied logistic regression analysis. Quantitative applications in the social sciences, No. 106. Thousand Oaks, CA \& London: Sage, 1995.

[60] T. Zhou, "Understanding mobile Internet continuance usage from the perspectives of UTAUT and flow. Information Development, 27(3), 207$218,2011$.

[61] T. Escobar-Rodríguez, E. Carvajal-Trujillo, "Online purchasing tickets for low cost carriers: An application of the unified theory of acceptance and use of technology (UTAUT) model” Tourism Management, 43, 70-88, 2014. 